\title{
Do terrestrial protected areas conserve freshwater fish diversity? Results from the Western Ghats of India
}

\author{
Robin Kurian Abraham and Nachiket Kelkar
}

\begin{abstract}
Terrestrial protected areas are often designated in inaccessible high elevation regions, and usually targeted towards conservation of charismatic large mammals and birds. It has been suggested that such protected areas, with partial coverage of riverine habitats, may not be adequate for conservation of freshwater taxa such as fishes. Also, protected areas are often designated in upstream catchments of dam reservoirs, and conservation of freshwater biodiversity is usually not a priority. We investigated the importance of existing protected areas for conservation of stream fishes within and across three dammed and two undammed rivers in the southern Western Ghats, India (a global biodiversity hotspot). Comparisons of stream sites in protected and unprotected areas were restricted to mid elevations because of confounding factors of dams, elevation and stream order. For dammed rivers, endemic and total species richness was significantly higher inside protected areas than unprotected areas. Total fish species richness increased with decreasing elevation and endemic species richness peaked at mid elevations. Species found in comparable stream orders across dammed and undammed midland river reaches were similar. Intensity of threats such as sand mining, dynamite fishing, pollution and introduced invasive fishes was higher in unprotected than in protected areas. Lack of awareness among managers has also led to the occurrence of some threats within protected areas. However, existing protected areas are vital for conservation of endemic fishes. Our results support the need for extending the scope of terrestrial protected areas towards better representation of freshwater ecosystems and biodiversity.
\end{abstract}

Keywords Diversity, fish, freshwater, India, Western Ghats This paper contains supplementary material that can be found online at http://journals.cambridge.org

\section{Introduction}

lobally, freshwater ecosystems have been severely $\checkmark$ affected by anthropogenic impacts on riverine

Robin Kurian ABRAHAm and NACHIKET KelKar (Corresponding author) TC 11/ 1123, YMR Junction, Kowdiar P.O., Nanthencode, Thiruvananthapuram 695 003, Kerala, India, and National Centre for Biological Sciences, Tata Institute of Fundamental Research, Bangalore, India. E-mail rainmaker.nsk@gmail.com

Received 28 January 2011. Revision requested 8 March 2011.

Accepted 14 May 2011. ecosystem services and resources (Allan \& Flecker, 1993; Collen et al., 2008). The widespread degradation of these ecosystems threatens aquatic biodiversity at both local and regional scales (Richter et al., 2003; Vörösmarty et al., 2010) and protecting freshwater ecosystems and biodiversity is a global challenge (Collen et al., 2008; Vörösmarty et al., 2010). Fishes are both an important component of freshwater diversity and a resource widely exploited for consumption and trade (Duncan \& Lockwood, 2001) and therefore an important aspect of river conservation (Cowx, 2002; Dudgeon et al., 2005).

Freshwater (riverine and wetland) protected areas have been proposed as a solution for conserving freshwater biodiversity, including fishes, and sustaining hydrological services (Saunders et al., 2002; Abell et al., 2007; Suski \& Cooke, 2007). Exclusively freshwater protected areas are uncommon, and protection of freshwater habitats (especially flowing waters) is mainly through terrestrial protected areas (Cowx, 2002; Abell et al., 2007).

However, terrestrial protected areas do not necessarily represent the overall diversity of landscape features, ecosystems or biodiversity (McNeely et al., 1994; SCBD, 2004; Rodrigues et al., 2004a,b). River protection or fish conservation are mostly incidental as part of terrestrial protected areas, which cover $<12 \%$ of inland waters (Pittock et al., 2008). In addition, designation of terrestrial protected areas is often biased towards high-elevation regions (Joppa \& Pfaff, 2009) and charismatic large mammals and birds (Rodrigues et al., 2004b).

In many developing countries protected areas are often created in the upper reaches of dam catchments, mainly for catchment protection and as compensation for inundation of forests under reservoirs (McNeely, 1987; McNeely et al., 1994; Stolton et al., 2010). Such protected areas may not be representative of linear river systems or their biodiversity along the gradient of elevation (Collares-Pereira \& Cowx, 2004; Becker et al., 2007; Nel et al., 2007, 2009; Herbert et al., 2010). Nevertheless, terrestrial protected areas are the most common measure for land-cover protection in many places (McNeely et al., 1994; SCBD, 2004; Pittock et al., 2008). Assessments are required of how effectively these protected areas conserve freshwater biodiversity (Chape et al., 2005; Nel et al., 2007; Gaston et al., 2008).

In the Western Ghats mountain range of India protected area coverage (9\%) mostly extends from mid-elevation 
forested areas in dam reservoir catchments to higher elevations at the crest of largely inaccessible escarpments and mountain ridges (Gunawardene et al., 2007). Construction of dams and reservoirs preceded the creation of most of these protected areas (Nair, 1991), which were later designated for conservation of threatened species of large mammals and birds (Das et al., 2006; Gunawardene et al., 2007). But dedicated conservation of so-called lesser taxa has always been lacking in these protected areas yet they are vulnerable to many threats. For example, native fish communities in this landscape have been identified as susceptible to the impacts of climate change and rapid urbanization (McDonald et al., 2011).

We report here an investigation of the effectiveness of terrestrial protected areas in the southern Western Ghats of India for the conservation of riverine and stream fishes. We know a priori that there are no protected areas in the lowlands and therefore that strictly lowland river fish species are unprotected. We use the number of regionally endemic and total fish species as the response variables to assess the effectiveness of protected areas for fish conservation (e.g. Bergl et al., 2007). Fish species richness was determined for river sites in unprotected and protected areas, and for dammed and undammed rivers. The study area has several potentially confounding ecological factors that could lead to incorrect inferences about the effectiveness of protected areas (e.g. Becker et al., 2007; Andam et al., 2008; Gaston et al., 2008; Joppa \& Pfaff, 2010). This is because protected areas are mostly at higher elevations and comparable unprotected sites are not available, and protected areas are additionally biased with respect to stream order. We therefore attempted to reduce the impact of these confounding factors as much as possible (Table 1). Further insight into the impact of protected areas was obtained by investigating the pattern of fish species richness along the elevation gradient, which was compared to documented patterns of species richness with altitude (Fu et al., 2004; Becker et al., 2007; Jaramillo-Villa et al., 2010). We also compared the intensity and occurrence of anthropogenic threats to streams in protected and unprotected areas, using

TABLE 1 Confounding ecological factors in assessments of the effectiveness of protected areas, with particular reference to this study.

\begin{tabular}{|c|c|c|c|c|}
\hline & Origin & Problems & Potential solutions & Context of this study \\
\hline $\begin{array}{l}\text { Non-random } \\
\text { location of } \\
\text { protected areas }\end{array}$ & $\begin{array}{l}\text { Biased towards higher } \\
\text { elevations \& inaccessible } \\
\text { areas }^{1} \text {. Only in mid-high } \\
\text { elevations }(100-1,700 \mathrm{~m}) \text { in } \\
\text { upper catchments of dam } \\
\text { reservoirs. Focus on } \\
\text { conservation of watersheds, } \\
\text { landscape features \& large } \\
\text { mammals. }\end{array}$ & $\begin{array}{l}\text { Difficult to find } \\
\text { corresponding } \\
\text { unprotected areas with } \\
\text { similar attributes, for } \\
\text { comparing biodiversity } \\
\text { values }\end{array}$ & $\begin{array}{l}\text { Find areas with } \\
\text { comparable sites, find } \\
\text { subsets within areas } \\
\text { where sites can be } \\
\text { matched }^{2}\end{array}$ & $\begin{array}{l}\text { Protected \& unprotected areas } \\
\text { have similar ecological } \\
\text { variables only in midland } \\
\text { areas }\end{array}$ \\
\hline $\begin{array}{l}\text { Environmental } \\
\text { gradients }\end{array}$ & $\begin{array}{l}\text { Elevation zones: lowlands } \\
0-30 \mathrm{~m} \text {, midlands } 30-200 \mathrm{~m} \text {, } \\
\text { highlands } 200-1,700 \mathrm{~m} . \\
\text { Stream order: } 4-7 \text { in lowland } \\
\text { areas, } 3-5 \text { in midland } \\
\text { unprotected areas \& } 1-4 \text { in } \\
\text { protected areas. Presence of } \\
\text { dams \& land-use type } \\
\text { correlated with elevation. }\end{array}$ & $\begin{array}{l}\text { Multiple confounding } \\
\text { factors, difficult to } \\
\text { attribute differences } \\
\text { in diversity explicitly to } \\
\text { protection }\end{array}$ & $\begin{array}{l}\text { Reduce impacts of } \\
\text { confounding factors, } \\
\text { find natural control } \\
\text { sites such that only } \\
\text { protection status } \\
\text { differs }\end{array}$ & $\begin{array}{l}\text { Comparisons of species } \\
\text { richness only between } \\
\text { midland sites (mid } \\
\text { elevation \& stream order } 4 \text { ). } \\
\text { Separating protected areas } \\
\text { \& unprotected areas, } \\
\text { comparing species richness } \\
\text { across dammed \& undammed } \\
\text { rivers. }\end{array}$ \\
\hline $\begin{array}{l}\text { Indicator } \\
\text { variables }\end{array}$ & $\begin{array}{l}\text { Comprehensiveness, adequacy, } \\
\text { representativeness, } \\
\text { effectiveness }{ }^{3} \text {, spatial coverage, } \\
\text { length of river within protected } \\
\text { areas, management, threats \& } \\
\text { downstream benefits } \\
\text { assessed }\end{array}$ & $\begin{array}{l}\text { Subjectivity \& lack of } \\
\text { generalizable } \\
\text { quantitative values }\end{array}$ & $\begin{array}{l}\text { Strict definition of } \\
\text { conservation targets, } \\
\text { assessing protected area } \\
\text { management, } \\
\text { effectiveness with } \\
\text { standard indicators, } \\
\text { assumptions \& } \\
\text { conditions }\end{array}$ & $\begin{array}{l}\text { Endemic species richness used } \\
\text { as main criterion to assess } \\
\text { ecological value of protected } \\
\text { areas. Protected area } \\
\text { effectiveness based on threats } \\
\text { \& awareness } \\
\text { levels of stakeholders, } \\
\text { from semi-structured } \\
\text { interviews \& direct } \\
\text { observation. }\end{array}$ \\
\hline
\end{tabular}

${ }^{1}$ Becker et al. (2007)

${ }^{2}$ Joppa \& Pfaff (2010)

${ }^{3}$ Linke et al. (2010); see also Fig. 2 and Appendix 1 


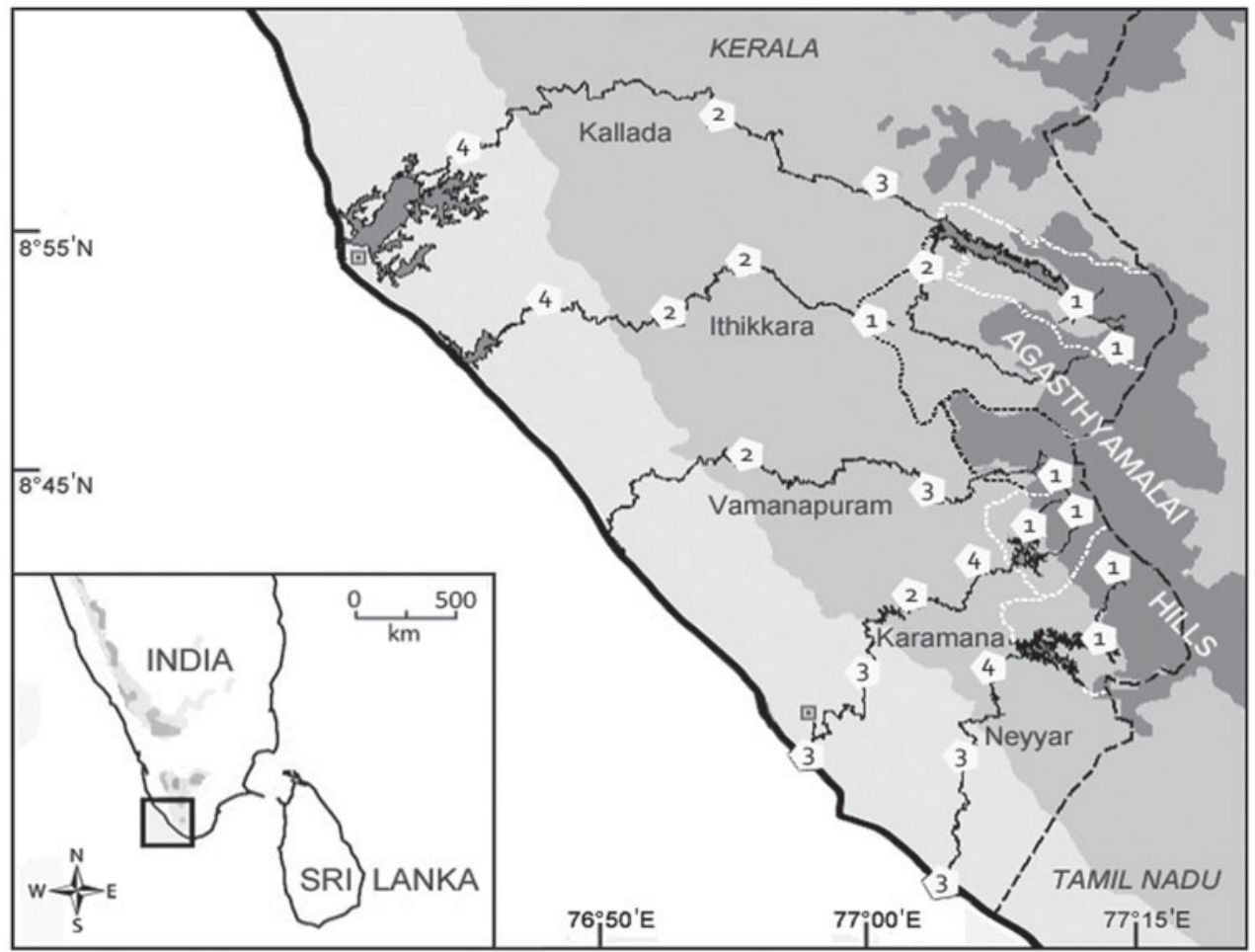

$\square$ Lowland $\square$ Midland $\square$ Highland \#: Threat scores for sites -- State Border ... RF boundary _- WLS boundary
FIg. 1 The Agasthyamalai Hills, Western Ghats, Kerala, showing the sampling sites, with their respective threat scores, the elevation gradient, and the five rivers (KalladaKulathupuzha, Ithikkara, Kallar-Vamanapuram, Karamana, Neyyar). The inset indicates the location of the main map in southern India. direct observations and interviews with local people and protected area managers.

\section{Study area}

The Western Ghats mountain range, a global biodiversity hotspot (Myers et al., 2000), runs along the west coast of India. Streams originating in these mountains form the headwaters of the many rivers that provide freshwater to the plains (Nair, 1991). Freshwater fish diversity is high, with 290 documented species of which $65 \%$ are endemic (Dahanukar et al., 2011). Our study area in the Agasthyamalai (Ashambu) Hills in Kerala state comprises five west-flowing rivers (Fig. 1, Table 2). The landscape is a unique biotope within the southern Western Ghats, with high diversity and endemism of plants, fungi, invertebrates, fishes and amphibians (Nair, 1991; Dahanukar et al., 2004; Gunawardene et al., 2007). The study area comprises five protected areas: three Wildlife Sanctuaries (Neyyar, Peppara and Shendurney) and two Reserve Forests (Kulathapuzha, Palode) in the midlands and highlands (Fig. 1). The Wildlife Sanctuaries lie in the upper catchments of dam reservoirs and the Reserve Forests occur in the higher reaches of undammed rivers; thus, coverage of midland reaches is variable across protected areas (Table 2). With the exception of the Ithikkara (which originates at c. $240 \mathrm{~m}$ altitude), all rivers originate above $1,500 \mathrm{~m}$ (Basak et al., 1995) and descend through an elevation and land-use gradient that includes protected areas (highlands/midlands), rubber plantations/ mixed-crop cultivation (midlands) and coconut/paddy/ mixed-crop cultivation in rural and urban lowland areas.

\section{Methods}

\section{Data collection}

Data collection included (1) sampling fish communities and measuring ecological variables across multiple sites in protected and unprotected areas, (2) semi-structured interviews with local stakeholders to assess their perceptions of the intensity of threats to stream fishes, and assigning threat scores to sampled sites, and (3) interviews with protected area managers to assess their knowledge of freshwater conservation.

\section{Fish species and ecological variables}

We surveyed fish at 24 sites across five rivers in the lowlands (o-30 m), midlands $(30-200 \mathrm{~m})$ and highlands $(200-1,700$ $\mathrm{m})$ during the post-monsoon season during 2009-2010. Flow conditions were relatively consistent across sites. Data were collected along river reaches at the various elevations. We collected fish by minimally invasive sampling from dusk to dawn (18.00-06.00) with gears suited to the nature of the river course, stream order, flow, presence of aquatic vegetation and local human disturbance, and released fish 
TABLE 2 The five rivers studied in the Agasthyamalai (Ashambu) Hills in Kerala (Fig. 1), the protected areas through which they flow, the total river length, the catchment area that lies within the midlands, and the length of river lying within the protected area.

\begin{tabular}{|c|c|c|c|c|}
\hline River & Protected area & $\begin{array}{l}\text { Total river } \\
\text { length }(\mathrm{km})\end{array}$ & $\begin{array}{l}\text { Midland catchment } \\
\text { area within protected } \\
\text { area }\left(\mathrm{km}^{2}\right)\end{array}$ & $\begin{array}{l}\text { River length } \\
\text { within protected } \\
\text { area }(\%, \mathrm{~km})\end{array}$ \\
\hline Kallada-Kulathupuzha $^{2}$ & $\begin{array}{l}\text { Shenduruney Wildlife Sanctuary, } \\
\text { Kulathupuzha Reserve Forest }\end{array}$ & 122.5 & 71 & $21.97(26.8)$ \\
\hline Ithikkara $^{0}$ & Kulathupuzha Reserve Forest & 72 & 1 & $6.9(5)$ \\
\hline Kallar-Vamanapuram $^{0}$ & Palode Reserve Forest & 87.5 & 1.7 & $11.43(10)$ \\
\hline Karamana $^{2}$ & Peppara Wildlife Sanctuary & 75.6 & 22 & $18.52(14)$ \\
\hline Neyyar $^{1}$ & Neyyar Wildlife Sanctuary & 67 & 49.5 & $33.73(22.6)$ \\
\hline
\end{tabular}

${ }^{0,1,2}$ The number of dams and large weirs constructed on these rivers

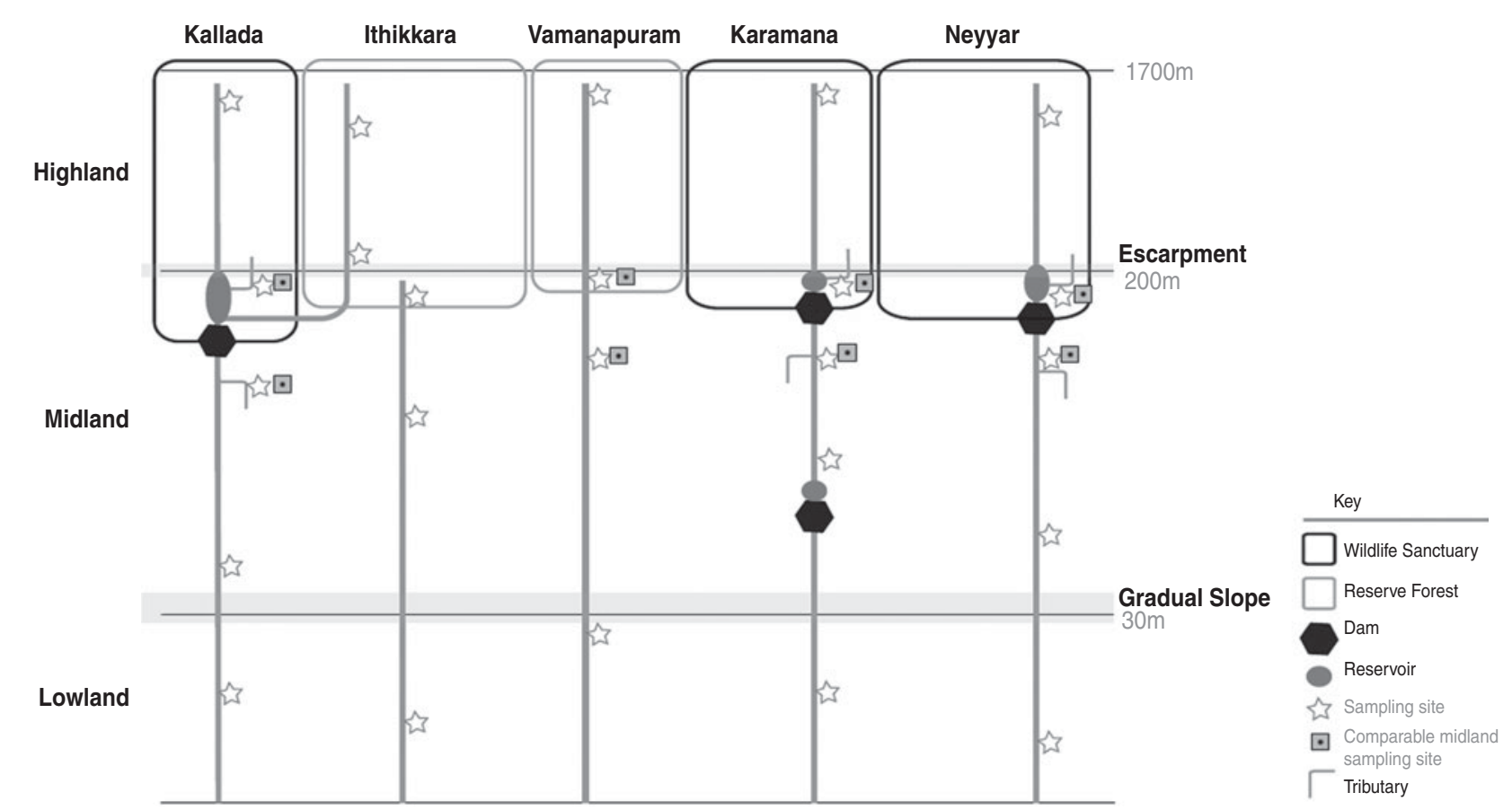

ARABIAN SEA

FIG. 2 Schematic diagram of the study area (Fig. 1), with the locations of the sampling sites on the five rivers (Kallada-Kulathupuzha, Ithikkara, Kallar-Vamanapuram, Karamana, Neyyar), protected areas and the occurrence of multiple confounding factors across elevation zones (see also Table 1).

after identification and specimen collection (total of 28 collected specimens deposited at the Museum, Department of Aquatic Biology and Fisheries, University of Kerala, Thiruvananthapuram). At each site we used cast nets with sufficient effort until local species saturation was obtained, and also conducted visual surveys for fish species. We deployed gillnets for highly mobile species and hooks and lines to sample larger predatory species, where possible. Fishes were identified using taxonomic keys and photographic documentation (see Abraham et al., 2011, for a review and checklist). Data on ecological variables (Appendix 1) were collected at each site. Anthropogenic threats were recorded and mapped, and protected area coverage in midland and highland areas was calculated using ArcView v. 3.3 (ESRI, Redlands, USA). Stream order was determined using 1:50,000 maps.

\section{Statistical analyses}

The number of fish species typically decreases with increasing altitude, and the number of endemic fish species has a hump-shaped relationship over the same change in altitude (Fu et al., 2004; Jaramillo-Villa et al., 2010). We used regression to describe the relationship between total and endemic fish species with altitude. For assessing whether protected areas have any effect on fish species richness we compared adjacent sites only with stream order 4 and similar altitudes (100-200 $\mathrm{m})$, in protected and unprotected areas. This eliminated the confounding effects of dams, elevation and stream order (Fig. 2). We compared species richness across dammed and undammed river sites separately to account for the potential confounding effect of dams. For all comparisons we used ANOVA to compare 
total and endemic species richness (square-root transformed) between protected and unprotected areas. Species can have heterogeneous detection or capture probabilities because of differences in habitat preferences and behaviour (Boulinier et al., 1998). To address this we obtained estimates of species richness from detection histories at all spatial replicates, with a Bayesian hierarchical model formulation. All other analyses in this study were performed using frequentist methods.

Bayesian hierarchical model formulation allows the specification of a prior probabilistic process model for the actual occurrence probabilities of species (based on checklists of fish from previous studies), followed by an observation model (for detectability) based on occurrence frequencies of sampled species drawn from the 'unknown' species richness of the area. This is based on Bayes Theorem $P(\theta \mid x) \propto P(x \mid \theta) \cdot P(\theta)$, i.e. the probability of the model parameters $\theta$ given the data $x$ (posterior probability) is proportional to the product of likelihood (probability of data $x$ given model $\theta$ and prior probability of $\theta$ ). We used the method developed by Royle \& Dorazio (2008) for estimating species richness under imperfect detection, with a procedure called data augmentation. In data augmentation 'species never sampled, but likely present' are added as all-zero detection histories. These added detection histories represent the prior process model for occurrence probability, and thus augment the existing detection data. Species added were from published occurrence records of fish species and consultations with fish taxonomists (Abraham et al., 2011). Uninformative prior distributions were used for occurrence and detection probabilities in the hierarchical model. This approach is analogous to estimation of closed populations based on sampled individuals (species in this case) with heterogeneity in detectability (Burnham \& Overton, 1978). Posterior estimates of species richness were obtained for stream sites within midland protected and unprotected areas, and for lowland sites. Statistical analyses were conducted using $R$ v. 2.11.1 (R Development Core Team, 2010) and WinBUGS (Spiegelhalter et al., 2007).

\section{Threats in protected and unprotected areas}

We conducted informal discussions and semi-structured interviews with local stakeholders (fishermen, farmers and rural citizens, and key informants; $\mathrm{n}=55$ ) to assess awareness and perception of threats to conservation of fish species and fish resources. On our interview datasheets (Appendix 2), threats for each site were categorized using the IUCN Red List Guidelines (IUCN Standards and Petitions Subcommittee, 2010) and ranked from most to least impact, based on stakeholder responses. Median threat scores were compiled from ranks assigned by interviewees to all prevalent threats at sites in protected and unprotected areas, and mapped. Protected area managers and staff were interviewed to assess their level of awareness and to discuss stream protection measures being undertaken within protected areas.

\section{Results}

\section{Species richness in protected and unprotected areas}

A total of 58 fish species were recorded. In each river, river segments in the protected area had consistently higher total species richness than segments in unprotected areas. The total number of species recorded in protected areas overall was 44, and 32 in unprotected areas. Estimated species richness was $57 \pm$ SD 10 and $50 \pm$ SD 14, respectively, in protected and unprotected areas. Lowland unprotected areas had the highest estimated total species richness (62 \pm SD 13; sampled richness $=29$ ), influenced by marine and estuarine species. We recorded the same 2-3 fish species in protected and unprotected highland sites (Table 3). For dammed rivers midland protected areas had significantly higher

TABLE 3 Number of fish species in three abundance categories (common, occasional, rare), number of endemic species and total number of species in dammed and undammed rivers in unprotected and protected areas in highlands, midlands and lowlands.

\begin{tabular}{|c|c|c|c|c|c|c|c|c|c|c|}
\hline \multirow[b]{2}{*}{$\begin{array}{l}\text { Protection status } \\
\text { (by elevation) }\end{array}$} & \multicolumn{5}{|c|}{ Dammed rivers } & \multicolumn{5}{|c|}{ Undammed rivers } \\
\hline & Common & Occasional & Rare & Endemic & $\begin{array}{l}\text { Total no. } \\
\text { of species }\end{array}$ & Common & Occasional & Rare & Endemic & $\begin{array}{l}\text { Total no. } \\
\text { of species }\end{array}$ \\
\hline \multicolumn{11}{|l|}{ Highlands } \\
\hline Unprotected & 0 & 1 & 0 & 1 & 1 & 1 & 1 & 0 & 1 & 2 \\
\hline Protected & 0 & 2 & 1 & 2 & 3 & 2 & 1 & 0 & 2 & 3 \\
\hline \multicolumn{11}{|l|}{ Midlands } \\
\hline Unprotected & 10 & 11 & 3 & 10 & 24 & 9 & 2 & 0 & 7 & 11 \\
\hline Protected & 22 & 11 & 4 & 13 & 37 & 9 & 4 & 1 & 10 & 14 \\
\hline \multicolumn{11}{|l|}{ Lowlands ${ }^{\star}$} \\
\hline Unprotected & 17 & 10 & 2 & 9 & 29 & 10 & 3 & 2 & 4 & 15 \\
\hline
\end{tabular}

${ }^{\star}$ There are no protected areas in lowlands 

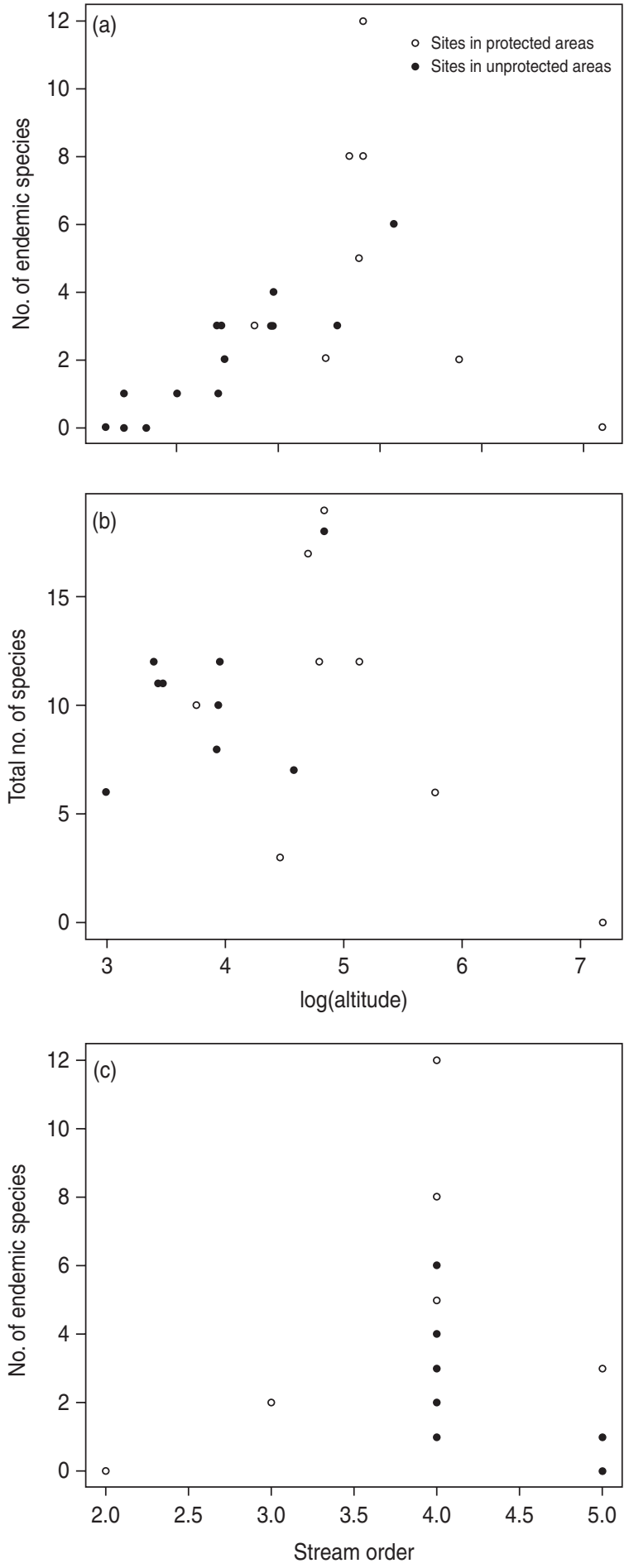

FIG. 3 Variation in (a) number of fish species endemic to the Western Ghats and (b) total number of fish species with log (altitude), and (c) number of endemic fish species with stream order.

regional endemic species richness (mean 5.11 \pm SD 3.78) than midland unprotected areas (mean $1.84 \pm$ SD 1.40 ; ANOVA: $\mathrm{F}=29.641, \mathrm{P}=0.00015 ; \quad$ Fig. 3a, Table 3). Endemic species richness exhibited a humped relationship with elevation (quadratic regression $R^{2}=0.396, \mathrm{P}=0.008$, $y=1.03+0.008 \times x-7.215 \times x^{2}$; Fig. 3 a) whereas total species richness declined with increasing elevation (Fig. 3 b). Across all rivers, sampled sites in protected areas had consistently higher endemic species richness than unprotected area sites of the same stream order (Fig. 3c). Total species richness in undammed rivers was less than in dammed rivers but endemic species richness was similar, with 10-14 species. Actual fish species recorded in dammed and undammed rivers were similar. Threatened as well as common fish species, and indigenous fishes of commercial importance, were encountered more commonly inside protected areas.

\section{Threats in protected and unprotected areas}

Threat scores were low inside protected areas and high at sites in midland and lowland unprotected areas (Table 4). Sand mining, dynamite fishing and acidic wastes disposed from rubber plantations, solid waste disposal, water pollution and proliferation of invasive exotic fish species were the most commonly recorded threats in unprotected areas (Table 4). There were also some threats, such as introduction of exotic food fishes in reservoirs, within protected areas. Most protected area managers lacked awareness about freshwater fish conservation, and no active measures for stream protection were being undertaken in the protected areas.

\section{Discussion}

Our analyses of mid elevation stream sites that were free of confounding factors show that sites within protected areas had a greater number of endemic fish species than sites in unprotected areas. Protected areas also had higher total species richness, and more threatened and common species (Devictor et al., 2007). As expected, endemic species richness peaked at mid-elevation sites whereas total species richness decreased with increasing altitude (Fu et al., 2004; Bergl et al., 2007; Jaramillo-Villa et al., 2010). For endemic species, there is a notable shift in the peak towards protected area sites at mid elevations, suggesting the importance of the protected status of these areas (Fig. 4). Terrestrial protected areas, through indirect protection of headwater streams and river zones, may offer refuge to midland fish species.

Studies of amphibians and reptiles in the Western Ghats have suggested that protected areas may not represent the entire range of altitudes or habitats, or distribution, of endemic species (Ishwar et al., 2001; Vasudevan et al., 2006). In Sri Lanka, for example, protected area coverage of endemic fish species of the wet zone (south-western midlands and associated plains) is poor (Pethiyagoda, 1994), as almost $95 \%$ of the protected areas cover dry zones at high altitudes.

However, for stream fish species of the southern Western Ghats our results indicate that a large percentage of endemic 
TABle 4 Threat scores $(1=$ least to $5=$ most $)$ to freshwater habitats and fish species. Note the differences in threat scores between unprotected and protected areas in midlands.

\begin{tabular}{|c|c|c|c|c|c|c|c|}
\hline Threats & Sand mining & Dynamite fishing & $\begin{array}{l}\text { Pollution from } \\
\text { rubber } \\
\text { plantations }\end{array}$ & $\begin{array}{l}\text { Urban- } \\
\text { industrial } \\
\text { pollution }\end{array}$ & $\begin{array}{l}\text { Solid } \\
\text { wastes }\end{array}$ & $\begin{array}{l}\text { Introduced alien } \\
\text { food fishes }\end{array}$ & Overfishing \\
\hline $\begin{array}{l}\text { Fishes } \\
\text { affected }\end{array}$ & $\begin{array}{l}\text { Substrate- } \\
\text { dwelling } \\
\text { fishes }\end{array}$ & $\begin{array}{l}\text { Indiscriminate; affects } \\
\text { all food fishes \& } \\
\text { predators }\end{array}$ & $\begin{array}{l}\text { Most food fish } \\
\text { species \& } \\
\text { endemics }\end{array}$ & $\begin{array}{l}\text { All native } \\
\text { fishes }\end{array}$ & $\begin{array}{l}\text { All } \\
\text { native } \\
\text { fishes }\end{array}$ & $\begin{array}{l}\text { Most endemics \& } \\
\text { common native } \\
\text { fishes }\end{array}$ & $\begin{array}{l}\text { Most native } \\
\text { food fishes }\end{array}$ \\
\hline \multicolumn{8}{|l|}{ Highlands } \\
\hline Unprotected & 1 & 1 & 1 & 1 & 3 & & \\
\hline Protected & 1 & 1 & 1 & 1 & 2 & & \\
\hline \multicolumn{8}{|l|}{ Midlands } \\
\hline Unprotected & 5 & 5 & 5 & 4 & 5 & 5 & 5 \\
\hline Protected & 2 & 2 & 1 & 1 & 3 & 4 & 1 \\
\hline \multicolumn{8}{|l|}{ Lowlands ${ }^{\star}$} \\
\hline Unprotected & 5 & 5 & 2 & 5 & 5 & 3 & 5 \\
\hline
\end{tabular}

*There are no protected areas in lowlands

species are represented in existing protected areas in the wet regions. Atkore et al. (2011), in a similar study, also reported higher fish species richness in rivers in a protected area above a dam reservoir compared to neighbouring undammed rivers in the Himalayan foothills. Existing terrestrial protected areas in the Western Ghats may thus be of importance to stream fishes, as has been shown for plants (Ramesh et al., 1997), and more directly comparable studies on similar taxa are required to support our results in the Agasthyamalai Hills landscape. However, prevailing terrestrial protected areas do not adequately represent the habitat diversity of river systems (McNeely et al., 1994; Stolton et al., 2010). This has been noted across various locations in different continents (e.g. Scott et al., 2001: Americas; Fitzsimons \& Robertson, 2005: Australia; Kotagama \& Bambaradeniya, 2006: Sri Lanka; Bergl et al., 2007: West Africa; Mukul et al., 2008: Bangladesh; Ioja et al., 2010: Romania; Jupiter et al., 2011: Fiji). The relatively few studies that have assessed the effectiveness of protected areas for freshwater species (e.g. Abellan et al., 2007; Bergl et al., 2007) show similar results to our study. Nonetheless, more species-focused assessments are required. The existing protected area coverage of river systems in the Western Ghats supports fish species adapted to primarily highland stream habitats. Protected area coverage therefore needs to be extended to include midland and lowland river reaches and associated riparian zones.

Protected areas of the Western Ghats ecoregion, being clustered in and around highlands, offer land-cover and stream protection by restricting human access and usage and consequently reducing anthropogenic pressure. In contrast, the absence of protection in lowland and midland river reaches has led to serious threats, including excessive sand mining, indiscriminate dynamite fishing, high levels of pollution (from rubber plantations and urban areas), and
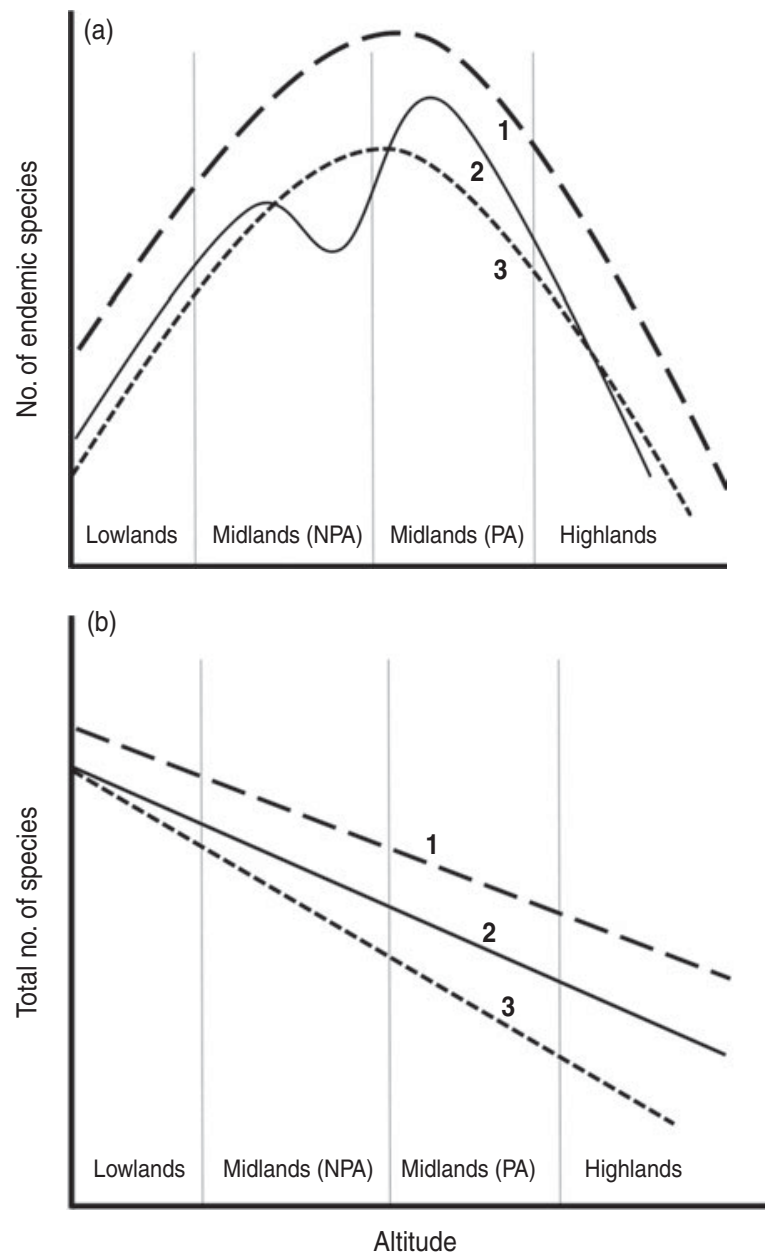

FIG. 4 Schematic summary of the results of this study: patterns of (a) endemic and (b) total species richness in dammed and undammed rivers with elevation (1, hypothetical expected relationship; 2, dammed rivers; 3 , undammed rivers; PA, protected areas; NPA, non-protected areas). Total species richness decreases with elevation whereas endemic species richness peaks in midlands, where it is higher in protected areas. 
widespread changes in surrounding land use. Despite protected area management not being directed towards stream protection, these threats are present at low intensity within protected areas. However, threats are not entirely absent. Excessive and irresponsible collection of freshwater fish by destructive sampling practices employed for trade and research in this region (Daniels, 2011) has been an unforeseen recent threat, even within protected areas.

To strengthen existing levels of freshwater habitat protection in protected areas (Nel et al., 2007), managers need to be made aware of the need to monitor and curb threats actively and manage these sensitive ecosystems knowledgeably. Also, fisheries officials need to be involved in conservation of native fishes in protected catchments of dam reservoirs, rather than managing reservoirs by introducing exotic fishes merely for profit-making initiatives. McNeely (1987) suggested that water development and catchment protection could be used to improve protected area coverage. Our results are thus relevant to most forested regions of the tropics, where protected areas have largely been designated around dam catchments (McNeely et al., 1994; Stolton et al., 2010). For instance, in Sri Lanka, Kotagama \& Bambaradeniya (2006) reported that protected areas cover highland dry zones, but not wet zone midland or lowland streams, possibly because of the presence of dams at higher elevations.

Midland protected areas may often be located in areas across escarpment bases that give way to gradual relief, which are optimal for the construction of irrigation dams. There is also the threat of imminent river interlinking projects in the Western Ghats aimed at joining east- and west-flowing rivers. These locations may coincide with stream reaches supporting high species turnover and occurrence of endemics (Sreekantha et al., 2007), where chances of their representation within protected areas may be higher. Correspondence of protected areas and dam reservoirs, despite contributing positively to protected area coverage of endemics, may have negative downstream impacts on stream flow regimes and sediment fluxes (Pittock et al., 2008). Transfer of benefits of stream protection to unprotected areas may be limited by sharp boundaries created by dams, which promote encroachment, illegal fishing and introduction of exotic invasive fish species (Hansen \& DeFries, 2007). These threats were also noted in our study area. Dams with protected area catchments afford relatively better protection to midland hill streams compared to dams with unprotected catchments. But the negative impacts of dams on native stream fishes considerably limit the benefits of such incidental protection. In 2011 the results from our study were successfully used in convincing the state forest and fisheries departments to reject proposals for introducing exotic fishes into dam reservoirs within protected areas (Nandakumar, 2010; Anon., 2011). However, additional efforts regarding ecologically sound land- and water-use policy need to be made to ensure that the indigenous freshwater diversity of this landscape, and of the wider Western Ghats, can be safeguarded in the long term.

Despite numerous threats, our results suggest that existing protected areas in the southern Western Ghats afford protection to many freshwater fish species and play an important role in conserving rare and endemic species. This study also provides a framework for further research on impacts of protected areas on biodiversity conservation in hill regions in the presence of confounding factors. We recommend the need for detailed ecological research, and greater awareness among protected area managers, to identify priority conservation areas for freshwater species and habitats (e.g. Hermoso et al., 2008; Roux et al., 2008). Payment for Ecosystem Services (PES) schemes are now increasingly being employed in conservation, providing an economic rationale for protecting social and ecological values (Wunder, 2012), especially in unprotected areas. Rubber plantations in our study region mark a significant modification of land-use practices. Threats to freshwater fishes are directly linked to land-use change, and PES-linked certification schemes have been recently initiated to develop sustainable practices in management of rubber plantations in this area (Feral-India, 2011). These initiatives, along with our results, support the need for expanding the present scope of terrestrial protected areas (Pittock et al., 2008) towards better representation of freshwater ecosystems and taxa.

\section{Acknowledgements}

We thank the Conservation Leadership Programme for funding, and the Kerala Forest Department for research permits and logistic support, and two anonymous reviewers and Geoff Hyde of the National Centre for Biological Sciences (NCBS), Bangalore, for constructive comments that greatly enhanced this article. We are also grateful to Uma Ramakrishnan of NCBS, and Ajith Kumar and Jagdish Krishnaswamy of the Wildlife Conservation Society-India for their continuous support, R. Rajesh, Chacko, Chandrankutty, Francis, Sukumaran and Thomas Ammavan for field assistance and logistic support, and A. Bijukumar, C.P. Shaji and Kurian Mathew Abraham who shared vital information and provided logistic support.

\section{References}

Abell, R., Allan, J.D. \& Lehner, B. (2007) Unlocking the potential of protected areas for freshwaters. Biological Conservation, 134, $48-63$.

Abellan, P., Sanchez-Fernandez, D., Velasco, J. \& Millan, A. (2007) Effectiveness of protected area networks in representing freshwater biodiversity: the case of a Mediterranean river basin 
(south-eastern Spain). Aquatic Conservation: Marine and Freshwater Ecosystems, 17, 361-374.

Abraham, R.K., Kelkar, N. \& Bijukumar, A. (2011) Freshwater fish fauna of the Ashambu Hills landscape, southern Western Ghats, India, with notes on some range extensions. Journal of Threatened Taxa, 3, 1585-1593.

Allan, J.D. \& Flecker, A.S. (1993) Biodiversity conservation in running waters. BioScience, 43, 32-43.

Andam, K.S., Ferraro, P.J., Pfaff, A., Sanchez-Azofeifa, G.A. \& Robalino, J.A. (2008) Measuring the effectiveness of protected area networks in reducing deforestation. Proceedings of the National Academy of Sciences of the USA, 105, 16089-16094.

Anon. (2011) No Plan to Release Exotic Fish Varieties into Reservoirs. The Hindu, India. Http://www.thehindu.com/todays-paper/ tp-national/tp-kerala/article1104500.ece [accessed 12 March 2012].

Atkore, V.M., Sivakumar, K. \& Johnsingh, A.J.T. (2011) Patterns of diversity and conservation status of freshwater fishes in the tributaries of the river Ramganga in the Shiwaliks of the western Himalayas. Current Science, 100, 731-736.

Basak, P., James, E.J. \& Nandeshwar, M.D. (1995) Water Atlas of Kerala. Central Water Resources Development and Management Institute, Calicut, India.

Becker, A., Korner, C., Brun, J., Guisan, J. \& Tappeiner, U. (2007) Ecological and land use studies along elevational gradients. Mountain Research and Development, 27, 58-65.

Bergl, R.A., Oates, J.F. \& Fotso, R. (2007) Distribution and protected area coverage of endemic taxa in West Africa's Biafran forests and highlands. Biological Conservation, 134, 195-208.

Boulinier, T., Nichols, J.D., Sauer, J.R., Hines, J.E. \& Pollock, K.H. (1998) Estimating species richness: the importance of heterogeneity in species detectability. Ecology, 79, 1018-1028.

Burnham, K.P. \& Overton, W.S. (1978) Estimation of the size of a closed population when capture probabilities vary among animals. Biometrika, 65, 625-633.

Chape, S., Harrison, J., Spalding, M. \& Lysenko, I. (2005) Measuring the extent and effectiveness of protected areas as an indicator for meeting global biodiversity targets. Philosophical Transactions of the Royal Society B: Biological Sciences, 360, 443-455.

Collares-Pereira, M.J. \& Cowx, I.G. (2004) The role of catchment scale environmental management in freshwater fish conservation. Fisheries Management and Ecology, 11, 303-312.

Collen, B., McRae, L., Kothari, G., Mellor, R., Daniel, O., Greenwood, A. et al. (2008) Living Planet Index. In 2010 and Beyond: Rising to the Biodiversity Challenge (ed. J. Loh). WWF, Gland, Switzerland.

Cowx, I.G. (2002) Analysis of threats to freshwater fish conservation: past and present challenges. In Conservation of Freshwater Fishes: Options for the Future (eds M.C. Pereira, I.G. Cowx \& M. Coelho), pp. 201-220. Fishing News Books, Blackwell Science, Oxford, UK.

Dahanukar, N., Raghavan, R., Ali, A., Abraham, R. \& Shaji, C.P. (2011) The status and distribution of freshwater fishes of the Western Ghats. In The Status and Distribution of Freshwater Biodiversity in the Western Ghats (Compilers S. Molur, K.G. Smith, B.A. Daniel \& W.R.T. Darwall), pp. 21-48. IUCN, Cambridge, UK, and Gland, Switzerland, and Zoo Outreach Organisation, Coimbatore, India.

Dahanukar, N., Raut, R. \& Bhat, A. (2004) Distribution, endemism and threat status of freshwater fishes in the Western Ghats of India. Journal of Biogeography, 31, 123-136.

Daniels, R.J.R. (2011) Miss Kerala in peril. Current Science, 101, 1518-1519.

Das, A., Krishnaswamy, J., Bawa, K.S., Kiran, M.C., Srinivas, V., Kumar, N.S. \& Karanth, K.U. (2006) Prioritization of conservation areas in the Western Ghats, India. Biological Conservation, 133, 16-31.

Devictor, V., Godet, L., Julliard, R., Couvet, D. \& Jiguet, F. (2007) Can common species benefit from protected areas? Biological Conservation, 139, 29-36.

Dudgeon, D., Arthington, A.H., Gessner, M.O., Kawabata, Z.I., Knowler, D.J., Lévêque, C. et al. (2005) Freshwater biodiversity: importance, threats, status and conservation challenges. Biological Reviews, 81, 163-182.

Duncan, J.R. \& Lockwood, J.L. (2001) Extinction in a field of bullets: a search for causes in the decline of the world's freshwater fishes. Biological Conservation, 102, 97-105.

Feral-India (2011) Exploring Sustainable Land-use Practices in Rubber Plantations in a Critical Wildlife Corridor. Http://www. feralindia.org/drupal/content/exploring-sustainable-landusepractices-rubber-plantations-critical-wildlife-corridor [accessed 5 March 2012]

Fitzsimons, J.A. \& Robertson, H.A. (2005) Freshwater reserves in Australia: directions and challenges for the development of a comprehensive, adequate and representative system of protected areas. Hydrobiologia, 552, 87-97.

Fu, C., Wu, J., Wang, X., Lei, G. \& Chen, J. (2004) Patterns of diversity, altitudinal range and body size among freshwater fishes in the Yangtze River basin, China. Global Ecology and Biogeography, $13,543-552$.

Gaston, K.J., Jackson, S.F., Cant'U-Salazar, L. \& Cruz-Pinon, G. (2008) The ecological performance of protected areas. Annual Review of Ecology, Evolution and Systematics, 39, 93-113.

Gunawardene, N.R., Dulip Daniels, A.E., Gunatilleke, I.A.U.N., Gunatilleke, C.V.S., Karunakaran, P.V., Nayak, K.G. et al. (2007) A brief overview of the Western Ghats-Sri Lanka biodiversity hotspot. Current Science, 93, 1567-1572.

Hansen, A.J. \& DeFries, R.J. (2007) Ecological mechanisms linking protected areas to surrounding lands. Ecological Applications, 17, 974-988.

Herbert, M.E., McIntyre, P.B., Doran, P.J., David Allan, J. \& AbELL, R. (2010) Terrestrial reserve networks do not adequately represent aquatic ecosystems. Conservation Biology, 24, 1002-1011.

Hermoso, V., Linke, S. \& Prenda, J. (2008) Identifying priority sites for the conservation of freshwater fish biodiversity in a Mediterranean basin with a high degree of threatened endemics. Hydrobiologia, 623, 127-140.

Ioja, C.I., Patroescu, M., Rozylowicz, L.J., Popescu, V.D., Verghelet, M., Zotta, M.I. \& Felciuc, M. (2010) The efficacy of Romania's protected areas network in conserving biodiversity. Biological Conservation, 143, 2468-2476.

Ishwar, N.M., Chellam, R. \& Kumar, A. (2001) Distribution of forest floor reptiles in the rainforest of Kalakad-Mundanthurai Tiger Reserve, South India. Current Science, 80, 413-418.

IUCN Standards and Petitions Subcommittee (2010) Guidelines for Using the IUCN Red List Categories and Criteria. IUCN, Gland, Switzerland. Http://intranet.iucn.org/webfiles/doc/ SSC/RedList/RedListGuidelines.pdf [accessed 11 June 2010].

Jaramillo-Villa, U., Maldonado-Ocampo, J.A. \& Escobar, F. (2010) Altitudinal variation in fish assemblage diversity in streams of the central Andes of Colombia. Journal of Fish Biology, 76, 2401-2417.

Joppa, L.N. \& Pfaff, A. (2009) High and far: biases in the location of protected areas. PLoS One, 4, 1-6.

Joppa, L.N. \& PFAFF, A. (2010) Reassessing the forest impacts of protection: the challenge of nonrandom location and a corrective method. Annals of the New York Academy of Sciences, $1185,135-149$. 
Jupiter, S., Tora, K., Mills, M., Weeks, R., Adams, V., Qauqau, I. et al. (2011) Filling the Gaps: Identifying Candidate Sites to Expand Fiji's National Protected Area Network. Outcomes report from provincial planning meeting. Wildlife Conservation Society, Suva, Fiji.

Kotagama, S.W. \& Bambaradeniya, C.N.B. (2006) An Overview of the Wetlands of Sri Lanka and Their Conservation Significance. IUCN Sri Lanka and the Central Government Authority, National Wetland Directory, Colombo, Sri Lanka.

Linke, S., Turak, E. \& Nel, J. (2010) Freshwater conservation planning: the case for systematic approaches. Freshwater Biology, 56, 6-20.

McDonald, R.I., Green, P., Balk, D., Fekete, B.M., Revenga, C., Todd, M. \& Mark Montgomery, M. (2011) Urban growth, climate change, and freshwater availability. Proceedings of the National Academy of Sciences of the USA, 108, 6312-6317.

McNeELy, J.A. (1987) How dams and wildlife can coexist: natural habitats, agriculture, and major water resource development projects in tropical Asia. Conservation Biology, 1, 228-238.

McNeely, J.A., Harrison, J. \& Dingwall, P. (1994) Protecting Nature: Regional Reviews of Protected Areas. IUCN, Gland, Switzerland.

Mukul, S.A., Uddin, M.B., Uddin, M.S., Khan, M.A.S.A. \& Marzan, B. (2008) Protected areas of Bangladesh: current status and efficacy for biodiversity conservation. Proceedings of the Pakistan Academy of Sciences, 45, 59-68.

Myers, N., Mittermier, R.A., Mittermier, C.G., Da FonsecA, G.A.B. \& Kent, J. (2000) Biodiversity hotspots for conservation priorities. Nature, 403, 853-858.

NAIR, S.C. (1991) Southern Western Ghats. Indian National Trust for Art and Cultural Heritage (INTACH), New Delhi, India.

Nandakumar, T. (2010) Move to Stock Reservoirs with Carp Runs into Opposition. The Hindu, India. Http://www.thehindu.com/news/ states/kerala/article948273.ece [accessed 12 March 2012].

Nel, J.L., Reyers, B., Roux, D.J. \& Cowling, R.M. (2009) Expanding protected areas beyond their terrestrial comfort zone: identifying spatial options for river conservation. Biological Conservation, 142, 1605-1616.

Nel, J.L., Roux, D.J., Maree, G., Kleynhans, C.J., Moolman, J., Reyers, B. et al. (2007) Rivers in peril inside and outside protected areas: a systematic approach to conservation assessment of river ecosystems. Diversity and Distributions, 13, 341-352.

Pethiyagoda, R. (1994) Threats to the indigenous freshwater fishes of Sri Lanka and remarks on their conservation. Hydrobiologia, 285, 189-201.

Pittock, J., Hansen, L.J. \& Abell, R. (2008) Running dry: freshwater biodiversity, protected areas and climate change. Tropical Conservancy: Biodiversity, 9, 31-39.

Ramesh, B.R., Menon, S. \& BAwa, K. (1997) A vegetation-based approach to biodiversity gap analysis in Agasthyamalai region, Western Ghats, India. Ambio, 28, 529-536.

R Development Core Team (2010) R: A Language and Environment for Statistical Computing. Vienna, Austria. Http://www.r-project.org [accessed September 2010].

Richter, B.D., Braun, D.P., Mendelson, M.A. \& Master, L.L. (2003) Threats to imperiled freshwater fauna. Conservation Biology, 11, 1081-1093.

Rodrigues, A.S.L., Akçakaya, H.R., Andelman, S.J., Bakarr, M.I., Boitani, L., Brooks, T.M. et al. (2004a) Global gap analysis: priority regions for expanding the global protected-area network. BioScience, 54, 1092-1100.

Rodrigues, A.S.L., Andelman, S.J., BaKarr, M.I., Boitani, L., Brooks, T.M., Cowling, R.M. et al. (2004b) Effectiveness of the global protected area network in representing species diversity. Nature, 428, 640-643.

Roux, D.J., Nel, J.L., Ashton, P.J., Deacon, A.R., De Moore, F.C., HARDWICK, D. et al. (2008) Designing protected areas to conserve riverine biodiversity: lessons from a hypothetical redesign of the Kruger National Park. Biological Conservation, 141, 100-117.

Royle, J.A. \& Dorazio, R. (2008) Hierarchical Modeling and Inference in Ecology - The Analysis of Data from Populations, Metapopulations and Communities. Academic Press, San Diego, USA.

Saunders, D.L., Meeuwig, J.J. \& Vincent, A.C.J. (2002) Freshwater protected areas: strategies for conservation. Conservation Biology, 16, 30-41.

SCbD (Secretariat of the Convention on Biological Diversity) (2004) Biodiversity Issues for Consideration in the Planning, Establishment and Management of Protected Area Sites and Networks. CBD Technical Series no. 15, Montreal, Canada.

Scott, M.J., Davis, F.W., McGhie, R.G., Wright, R.G., Groves, C. \& Estes, J. (2001) Nature reserves: do they capture the full range of America's biological diversity? Ecological Applications, 11, 999-1007.

Spiegelhalter, D.J., Thomas, A., Best, N.G. \& Lunn, D. (2007) WinBUGS Version 1.4.3 User Manual. MRC Biostatistics Unit, Cambridge, UK.

Sreekantha, M.D., Mesta, D.K., Rao, G.R., Gururaja, K.V. \& Ramachandra, T.V. (2007) Fish diversity in relation to landscape and vegetation in central Western Ghats, India. Current Science, 92, 1592-1603.

Stolton, S., Mansourian, S. \& Dudley, N. (2010) Valuing Protected Areas. Report for the World Bank's Global Environment Facility Coordination Team. World Bank, Washington, DC, USA.

Suski, C.D. \& CoOKE, S.J. (2007) Conservation of aquatic resources through the use of freshwater protected areas: opportunities and challenges. Biodiversity and Conservation, 16, 2015-2029.

Vasudevan, K., Kumar, A. \& Chellam, R. (2006) Species turnover: the case of stream amphibians of rainforests in the Western Ghats, southern India. Biodiversity Conservation, 15, 3515-3525.

Vörösmarty, C.J., McIntyre, P.B., Gessner, M.O., Dudgeon, D., Prusevich, A., Green, P. et al. (2010) Global threats to human water security and river biodiversity. Nature, 467, 555-561.

Wunder, S. (2012) Of PES and other animals. Oryx, 46, 1-2.

\section{Appendices}

The appendices for this article are available online at http://journals.cambridge.org

\section{Biographical sketches}

Robin Kurian Aвraham is an ecologist interested in the diversity of freshwater ecosystems and their conservation. He has carried out extensive surveys of the freshwater fish and amphibian diversity of the southern Western Ghats. His key research interests are in the fields of biogeography and aquatic ecology. He is also interested in using science-based conservation as a tool to develop solutions to existing problems affecting natural ecosystems and processes. NACHIKET KELKAR is a wildlife researcher currently involved in research projects on river dolphins, green turtles, and fish communities in rivers, streams, estuaries, coral reefs and seagrass meadows. His main research interests are in animal population estimation, spatial ecology and statistical modelling. 